Accepted version downloaded from SOAS Research Online: http://eprints.soas.ac.uk/26078

Management International Review

https://doi.org/10.1007/s11575-018-0361-3

\title{
Industry agglomeration, sub-national institutions and the profitability of
} foreign subsidiaries

\author{
Xiaoying $\mathrm{Li}^{1}$, Yin-Fang Zhang ${ }^{2}$, Laixiang Sun ${ }^{3,4}$ \\ ${ }^{1}$ Keele Management School, Keele University, Keele, UK \\ ${ }^{2}$ School of Environment, Education and Development, Global Development Institute, \\ University of Manchester, Manchester, UK \\ ${ }^{3}$ Department of Geographical Sciences, University of Maryland, College Park, MD, USA \\ 4 School of Fiance \& Management, SOAS University of London, UK
}

\section{ABSTRACT}

This study investigates the impact of agglomeration and its interaction with subnational institutions on the profitability of multinational enterprises (MNEs) subsidiaries operating in an emerging economy. We argue that in an emerging economy like China, competition in product and factor markets is more intense between foreign firms than between foreign and domestic firms owing to market segmentation. Consequently, agglomerating with other foreign firms has negative impact on the profitability of foreign subsidiaries. In contrast, foreign firms agglomerating with domestic firms may reap gains owing to less competition and improved access to local resources and knowledge. We find that these effects are more pronounced to domestic-market-oriented foreign firms. Furthermore, sub-national institutions moderate the above relationships. Our arguments are supported by the empirical analysis based on a comprehensive dataset of foreign firms operating in china over the period of 19992005 .

Acknowledgements Laixiang Sun acknowledges the financial support of Economic and Social Research Council and National Natural Science Foundation of China (ESRC-NSFC, $\mathrm{RC}$ grant reference ES/P005241/1). 


\section{INTRODUCTION}

Where to set up subsidiaries is an important strategic decision for multinational corporations (MNCs). While traditional studies focus on the choice of a host country, more recent studies have found that the selection of sub-national location also matters because regions within a host country vary in endowments which constitute sources of comparative advantage and present unique investment opportunities for MNCs (Chang and Park, 2005; Du, Lu and Tao, 2008a; Meyer and Nguyen, 2005; Stallkamp, Pinkham, Schotter and Buchel, 2017; Tan and Meyer, 2011). Another critical aspect of the location choice is whether to locate geographically close to other firms. Received wisdom suggests that industry agglomeration entails increasing returns to scale through dense interactions among firms, motivating firms to cluster geographically. However, there are negative externalities of agglomeration, arising from intensified competition (Baum and Mezias, 1992) and/or knowledge spillovers to rival firms (Shaver and Flyer, 2000). Although extant research has enriched the understanding of entry strategies of MNCs, there is limited empirical evidence of the effects of their location choice on performance. This paper attempts to fill in the gap by investigating the impact of industry agglomeration on the profitability of MNC subsidiaries in the context of the world's largest emerging economy - China, and examining how the effect is moderated by one particular subnational condition, namely institutions.

Most existing studies on the effects of agglomeration on firm performance tend to focus on productivity and highlight productivity gains arising from agglomeration economies. Although important, productivity is not the primary element firms in competitive industries aim at. Moreover, a positive relation between agglomeration and productivity does not necessarily drive location choice if the drawbacks of co-locating more than offset the productivity gains. As there are benefits as well as costs of agglomeration, higher productivity does not tell the full 
story about the net effect of clustering. This paper is motivated to examine the impact of agglomeration on profitability, a variable better accommodating both positive and negative effects of co-locating and an aspect of performance with, so far, very little empirical evidence.

In the international business literature, a recognition has recently been made that subnational factors are significant in explaining variations in foreign firm performance (e.g. Chan, Makino and Takehiko, 2010; Ma, Tong and Fitza, 2013). One of such factors is the institutional environment, which form location-specific conditions that entail the formation of routines of economic behaviour (Scott and Storper, 2003) and thus have a persistent influence on firm strategy and performance (Griffiths and Zammuto, 2005; Peng, 2003). In this paper, we examine the role of sub-national institutions in moderating the impact of industry agglomeration on profitability of MNC subsidiaries.

We choose China as the empirical setting of analysis for the following reasons. First, China has experienced rapid economic growth over the last three decades and become the largest recipient of foreign investment among developing countries since the early 1990s (UNCTAD, 2008). Second, it has gone through a major economic transition process while weaknesses in its formal and informal institutions remain major obstacles for businesses. Moreover, economic liberalization has been implemented unevenly across regions, which permits the exploration of the implications of institutional variation within a country for firm performance.

Based on industry agglomeration theory and institution-based view of strategy, we argue in this paper that the impact of industry agglomeration depends on the types of firms with which MNC subsidiaries choose to co-locate. In an emerging economy, industry agglomeration with other foreign firm subsidiaries may have a different impact on profitability than co-locating with domestic firms. Specifically, we contend that agglomerating with other foreign firms in the same industry has a negative impact on MNC subsidiaries' profitability while clustering with local firms in the same industry has a positive impact. Our hypotheses are tested on a large 
sample of 8,640 foreign firms in China over the period of 1999-2005, and our empirical results support the aforementioned argument. Moreover, we find weak sub-national institutions, by which we mean a context that is weak in supporting and facilitating market transactions, amplify the negative impact of agglomerating with other foreign firms and weaken the positive effect of co-locating with domestic firms. The findings are not only a description of foreign subsidiaries and domestic firms for the sample period, but also relevant for China today. These findings are also applicable to other emerging economies in their early stage of liberalization and at similar development stage with China.

The remainder of the paper proceeds as follows. The next section provides the theoretical arguments and sets out research hypotheses. The third section discusses data and methodology. The empirical results are presented in the fourth section, before concluding remarks are made in the last section.

\section{THEORY AND HYPOTHESES}

\section{Industry agglomeration and profitability of foreign subsidiaries in an emerging economy}

When examining the effects of agglomeration, it is useful to distinguish between different types of agglomeration. The urban study literature focuses on spatial agglomeration of unrelated firms, or urbanization economies, which is the concentration of general economic activity within a geographic area. In industrial organization and management research, agglomeration often refers to geographic clustering of firms in the same industry. Following the latter strand, we define agglomeration in this paper as co-locating with firms in the same industry, i.e., industry agglomeration, but make distinction between whether the agglomeration is with foreign or domestic firms, for the reason explained in the rest of the sub-section. 
The literature on agglomeration's impact on firm performance is growing, but very few studies have focused on firms' profitability ${ }^{1}$. Generally speaking, firms' profits will increase when there is improvement in productivity, ceteris paribus, and will decrease when costs rise relative to product prices (or profit margin squeezes) ${ }^{2}$. Agglomeration may impact on profitability on both fronts. The main argument which associates agglomeration with productivity lies with external scale economies. Marshall (1920) highlights three benefits that firms obtain when locating near each other, namely labour market pooling, input sharing, and knowledge spillovers. Porter (1980) provides a complementary view by looking at five sources of agglomeration economies: i) improved accessibility to specialized factors and workers; ii) improved access to information about market and technology trends; iii) promotion of complementarities and cooperation among firms; iv) improved access to infrastructure and public goods; and v) increased competitive pressure among firms. Firms anchored in clusters are arguably able to achieve, on average, higher productivity than isolated companies (Cohen and Paul, 2005; Tveteras and Battese, 2006), which may consequently be translated into higher profitability.

However, industrial agglomeration has downside as well. One disadvantage of clustering comes from increased competition in the product market, with clustered firms competing more intensively with geographically proximate competitors (Baum and Mezias, 1992; Hannan and Carroll, 1992; Ingram and Inman, 1996). While it may compel firms to improve efficiency,

\footnotetext{
${ }^{1}$ The exceptions include Asche, Roll and Tveteras (2016), Jennen and Verwijmeren (2010), Nguyen, McCracken, Casavant and Jessup (2011), Stavropoulos and Skuras (2016).

${ }^{2}$ The two mechanisms may overlap but not necessarily be the same. For instance, improvement in efficiency or productivity may lead to cost reduction and in turn high profitability; but cost reduction can be achieved through channels other than productivity improvement (such as the use of cheaper inputs).
} 
intensified competition more likely drives prices down, narrowing profit margins ${ }^{3}$. Siba, Soderbom, Bigsten and Gebreeyesus (2012) provide empirical evidence that agglomeration has a negative impact on output prices. Intensified competition also exists among agglomerating firms for scarce local resources and inputs, which couples with exacerbated congestion in access to infrastructure and public goods, pushing up human resource costs and land rents. Yet another downside of agglomeration lies with some kinds of knowledge spillovers ${ }^{4}$. Shaver and Flyer (2000) empirically show that, for firms which are strong in technologies, human capital, and other capabilities, the costs of knowledge spillovers outweigh the benefits because they contribute to the spillovers which benefit their rivals. Similar arguments are made by Appold (1995) which finds that industry agglomeration decreases performance in the metalworking sector, and by Yoffie (1993) which reports that managers in the semiconductor sector locate their new production away from competitors to avoid knowledge being spilled over to rivals. All these disadvantages of agglomeration lead to less productivity gains and/or increased costs, hence negatively impacting firms' profitability.

As agglomeration can generate both positive and negative externalities, the net result on profitability depends on which effect is stronger. When it comes to the profitability of MNC subsidiaries, we contend that the effect of agglomeration also hinges upon whether they cluster with domestic or other foreign firms. In an emerging economy, foreign subsidiaries typically possess superior technologies and strong brands, in contrast to domestic firms which are usually inferior in these aspects. This distinction may lead to market segmentation, with domestic firms

\footnotetext{
${ }^{3}$ The industrial organization literature argues that high seller concentration facilitates collusion and allows firms to earn supra-competitive profits (Bain, 1951; Schmalensee, 1989). However, such a market structure is not applicable to most of the industries we look at in the context of China's manufacturing.

${ }^{4}$ While there has been empirical evidence that knowledge spillovers to competitors may negatively impact firm performance, it should be noted that the relationship between knowledge leakages and firm profitability at the subsidiary level is ambiguous, particularly because MNEs are integrated networks. We thank an anonymous referee for making this observation.
} 
concentrating in the mid-to-low-end segment and foreign firms targeting consumers in the midto-high-end segment by providing products of higher quality (or perceived so) at higher prices (Luo, 2007). This is true of the early years of China's reform and the sample period of our study. The market of smartphone handsets presents an excellent example of such segmented competition, where the product prices ranged between 400 and 4,500 Yuan (or US\$64-720) in China in July 2012. Foreign multinationals like Apple and Samsung competed mainly in the high-end segment with high profit margins, Chinese multinationals like Huawei, Coolpad, Lenovo, and ZTE competed mainly in the medium-end segment, and small local brands like Yulong, Gionee, K-Touch and many others dominated in the low-end part of the market (Geng, 2012; Hille, Mundy, and Mishkin, 2012; Wang, 2012) ${ }^{5}$. Another example is the automotive industry in China (Thun, 2006).

It should be noted that innovative capabilities of Chinese firms have improved in recent years (Yip and McKern, 2016) and there has been an "explosion” of patent filings by indigenous enterprises. However, as noted by Eberhardt, Helmers and Yu (2017), patenting has highly concentrated among a small number of firms, operating in the information and communication technology sector. A notable case of the improvement in competitiveness of domestic firms is Huawei, which used to be a telecommunications equipment manufacturer with substantial market shares in the medium-end segments of the domestic market and has now become one of the world's leading brands in the industry. Nonetheless, the occurrence of rapid catching up has only limited to a few indigenous firms in a few industries. In most of other manufacturing industries, for example, automotive manufacturing, there is still market segmentation with foreign firms dominating the high-end market and domestic firms competing in the low- and

\footnotetext{
${ }^{5}$ The smartphone market in China is changing fast, with some China-originated brands becoming increasingly strong competitors in the high-end segment. However, the dominance of foreign firms in the high-end and domestic firms in the mid- and low-end of the market was typical of not only the smartphone market but also other products during our sample period.
} 
medium segments. In fact, even in the case of smartphone handset manufacturing, the majority of other domestic firms still target low- and medium-end customers. In other words, the competition landscape between foreign and domestic firms in many manufacturing industries has not changed significantly. Therefore, the above theoretical argument is arguably applicable, to some extent, to the situation in China today.

Apart from targeting similar market segments, competition among foreign firm subsidiaries is fierce also because of their similarity in resource and capability endowments in the form of advanced technologies, brand names, and managerial know-how (Baum and Mezias, 1992; Chang and $\mathrm{Xu}, 2008$; Teece, Pisano, and Shuen, 1997). Furthermore, they may compete intensely when they are in demand for local-bounded resources, such as a network with local governments, marketing channels, and experienced managers with extensive local knowledge. Intensified competition among foreign firms may also force them to fight for scarce local resources not only as inputs but also for the purposes of overcoming the liability of foreignness and obtaining legitimacy (Fischer and Harrington, 1996; Lamin and Livanis, 2013).

In other words, the main competitors of foreign firms are typically other foreign firms in the same industry rather than domestic firms. When clustering together, competition among MNC subsidiaries in both the product and factor markets becomes fiercer, making larger the adverse effects on costs and product prices. Hence, agglomeration with other foreign firms has negative impact on the profitability of foreign subsidiaries. To counteract such effects, foreign firms may choose to use product differentiation to mitigate direct competition, which allows them to command a premium price or sell more products at a given price (Canina, Enz, and Harrison, 2005). However, differentiation comes with increased costs, and a firm only enjoys success with this strategy if the gains in revenues exceed the costs (Porter, 1985). The concern is that other MNC subsidiaries may quickly imitate the innovations of leading firms, enjoying some of the benefits while absorbing fewer of the costs (Barney, 1991). Given their similarity 
in strategic resources and capability, technology and knowledge know-how involved in product differentiation is harder to keep secret when affiliates of foreign firms locate proximately.

Agglomerating with domestic firms may, however, present a different story. Dominating in different segments of a given market, foreign and domestic firms are not the fiercest competitors to each other, suggesting that the potential negative effects on profitability is much smaller. A major concern for foreign firms is technology spillovers to local firms. Despite earlier evidence of such spillovers, more recent empirical studies find that the meaningful spillovers are vertical rather than horizontal (Javorcik, 2004). The integrating system of MNCs can also protects their core technologies from spilling over to local firms (Zhao, 2006). Furthermore, the technology gap between foreign firms and domestic ones in an emerging economy is often wide (Tan and Meyer, 2011), constraining the latter's absorptive capability even when there are spillovers. Hence, probability of negative externalities from clustering with domestic firms is small. In fact, foreign firms may benefit from co-locating with domestic firms because the latter may help the former access to local knowledge, resources, and network connections (Beamish, 1988; Lu and Xu, 2006). For instance, in an emerging economy with weak institutions, domestic firms also need to spend substantial efforts and resources in dealing with governments to obtain permission to conduct certain business activities. Some permissions or privileges obtained can be applicable to the whole industry and thus benefit foreign firms as well. This is called "rent spillover" effect (Du et al., 2008a). In short, the productivity gains may outweigh the adverse impact on costs when clustering with domestic firms.

Two hypotheses are derived from the discussion so far:

Hypothesis la: In an emerging economy, agglomeration with other foreign firms in the same industry has a negative impact on the profitability of a foreign firm subsidiary.

Hypothesis 1b: In an emerging economy, agglomeration with domestic firms in the same industry has a positive impact on the profitability of foreign firm subsidiaries. 
It should be noted that the above discussion is more applicable to the situation where MNC subsidiaries sell bulks of their products to the domestic market in the host country. There are many subsidiaries of foreign firms targeting international markets, which are arguably less affected by the co-location of competitors and may rely less on local marketing and distribution channels and local knowledge possessed or facilitated by domestic firms although they may still benefit from local pools of skilled labour and managerial and technical staff, as well as cheaper and/or quality resources used as inputs. Therefore, we predict that the above two hypotheses are more relevant to domestic market-oriented foreign firm affiliates ${ }^{6}$. Thus, we have another hypothesis as follows:

Hypothesis 2: In an emerging economy, the negative impact of agglomeration with other foreign firms and the positive impact of clustering with domestic firms are more pronounced in domestic market-oriented foreign subsidiaries than in export-oriented foreign subsidiaries.

\section{Moderating effects of sub-national institutions}

Institutions are seen as 'the rules of the game' to govern economic transactions (North, 1990), or as systems of established and prevalent values and action patterns which provide stability and meaning to social behaviour (DiMaggio and Powell, 1983; Meyer and Rowan, 1977; Scott, 1995). In the international business literature, an institution-based view is developed to argue that the institutional context not only determines the comparative advantage of one location relative to another, but also shapes foreign investors' decision on entry mode through affecting their preference for internalizing markets and influencing how and what

\footnotetext{
${ }^{6}$ We thank an anonymous referee for this input.
} 
resources and capabilities they need to develop to gain legitimacy and reduce transaction costs (Brouthers, 2002; Henisz, 2000; Holmes, Miller, Hitt, and Salmador, 2013; Javorcik and Wei 2009; Meyer and Nguyen, 2005; Meyer, Estrin, Bhaumik and Peng, 2009; Peng and Heath, 1996).

Foreign firms face great uncertainty when operating in an institutional context different from their home countries. They need to decide not just about which country to enter but also which specific location within the country to invest (Du et al., 2008b; Meyer and Nguyen, 2005; Shaver and Flyer, 2000). Their choice of operating in a particular sub-national region is expected to bear on the survival and profitability of the subsidiary. It is especially true when the host country is an emerging economy like China, which is culturally and ethnically diverse, with substantial within-country heterogeneity in informal institutions. There are also variations in formal institutions among sub-national regions, due to uneven roll-out of market-oriented reforms, differences in locally set and implemented policies, and heterogeneity in local enforcement of centrally imposed rules (Naughton, 2007; Xu, 2011).

Institutions matter because they determine the cost of doing business and shape firms' strategy to interact with each other and with other stakeholders in order to reap opportunities and overcome obstacles presented in the environment they operate (Fisman, 2001; Khanna and Rivkin, 2001). They also impact on transformation costs of production through providing different incentives for innovation and influencing firms' choice of production technology (Bental and Demougin, 2006; Prescott, 1998). Institutions at sub-national levels present unique opportunities and challenges and exert direct and immediate influence on firms' transaction and transformation costs. We therefore argue that, in regions where institutions are weak, uncertainty faced by firms is acute and costs incurred in doing business are high, adversely impacting on the profitability of MNC subsidiaries. 
More importantly, we contend that sub-national institutions influence firms' profitability through affecting the nature and extent of agglomeration effects. As discussed earlier, colocating with foreign peers in the same industry may negatively impact on an MNC subsidiary owing to knowledge and resources spillovers and intensified competition. In regions with weak institutions, such spillovers become a more serious concern for foreign firms due to insufficient intellectual property right protection, reducing their competitiveness in relation to both direct rivals (mainly other foreign firms in the industry) and secondary rivals (mainly domestic firms in the industry). With weak institutions, MNC subsidiaries find themselves compete with each other not only in product and factor markets but also for resources used for reducing institutional uncertainty and transaction costs. In addition, competition for such resources will bid up the amount of resources and efforts needed to obtain what foreign firms want to achieve, which could otherwise be put into more efficient uses, adversely impacting on their profitability.

Weak institutions also attenuate the benefits foreign firms can draw from agglomerating with local firms. While an established cluster of local firms may mean a powerful interest group's collective action to influence policy in its favor (Laffont and Tirole, 1991; Olson, 1965), firms in the related industry may also be the main source and target for corrupt, rent-seeking local officials to seek bribes. Uncertainty is high in regions with weak institutions. Facing high uncertainty, local firms may be more interested in harvesting short-term gains than engaging in activities which bring long-term benefits but incur immediate costs, such as investing in staff training and industry-specific assets, thus reducing local resources sought by foreign investors. In regions with inefficient contract enforcement, developing trust and forming social networks with local firms are valuable social assets for foreign firms (Peng and Heath 1996; RoseAckerman, 2001). Local firms may also value such social capital which allows them to learn from foreign firms in order to upgrade and catch up (Lamin and Livanis, 2013) or at least outcompete their local peers. However, with high uncertainty, local firms are likely to engage 
in opportunistic behaviour and break up trust and network established with foreign firms if such actions have the possibility to bring them immediate benefits. All these tend to reduce the benefits of co-locating with local firms. Therefore, we establish the following hypotheses:

Hypothesis 3a: At sub-national level, weak institutions amplify the negative impact of industry agglomeration with other foreign firms on the profitability of foreign subsidiaries. Hypothesis 3b: At sub-national level, weak institutions reduce the positive impact of industry agglomeration with domestic firms on the profitability of foreign subsidiaries.

The discussions of this section are illustrated in Figure 1.

\section{(Figure 1 about here)}

\section{DATA AND METHODOLOGY}

\section{Data and sample}

Our hypotheses are tested using China as the empirical context, drawing data from various sources. The data on sub-national institutions are collected from the World Bank (2006) survey, which covers 120 cities in China and contains indicators on government effectiveness and investment environment. The sample of foreign firms used in our analysis is constructed combining data from the Annual Census of Industrial Enterprises 1999-2005 (the Census thereafter) complied by the State Statistical Bureau of China, and the Survey of Foreigninvested Industrial Enterprises in China 2001-2002 (the Survey thereafter) conducted by the Ministry of Foreign Trade of China. The Census covers all firms (domestic and foreign invested) with sales exceeding 5 million $\mathrm{RMB}$, which is about US\$60,500 using the exchange rates in 
effect during the sample years ${ }^{7}$. From this database, we obtain observations on foreign-invested firms with data on ownership structure, industry affiliation, location of register, year of establishment, number of employees, gross output, and other operational and financial indicators, from which we construct our dependent and most independent variables.

The initial pool of foreign firms includes those invested by overseas Chinese from Hong Kong, Macao and Taiwan, and those originated from offshore financial centres such as British Virgin Islands and Cayman Islands. Firms in the former group are often considered nonrepresentative of "truly foreign firms" (Du et al, 2008b; Li et al. 2009). The ethnic Chinese economies and the regions in the latter group are main sources of round-tripping FDI to China (Xiao, 2004). We exclude firms from these origins in the sample. To do so, we need to know the source countries of the sample firms. Such information is obtained from the Survey, which covers over 150,000 foreign firms in China from more than 50 source countries. Matching the two databases and dropping the firms from the said origins, we further restrict our sample to firms in the 120 cities for which we have data on institutional indicators. This approach does not comprise the representativeness of our sample because the data suggest foreign firms in these cities account for more than 90 percent of FDI in China. We are then left with a sample of more than 12,000 foreign firms, from which we subsequently exclude those which changed ownership over the sample period and those with observations for less than two consecutive years. After conducting the usual procedures to eliminate observations with illogical or extreme values, we arrive at a final sample of 8640 firms in 173 three-digit industries, totalling 37,713 firm-year observations.

\footnotetext{
${ }^{7}$ The number of firms covered in the database varies from one year to another, ranging from 162,033 to 280,188 . They account for 85-90 percent of total manufacturing output in China. The data from the Census have been used in many prior studies, e.g. Chang and Xu (2008) and Li, Zhou, and Zajac (2009).
} 


\section{Variables and Measures}

\section{Indicator of firm performance}

We measure the profitability of foreign firm subsidiaries (the dependent variable) by the return on sales (ROS) instead of return on assets (ROA). The former indicator is calculated using total sales as the numerator and the latter using fixed assets. Because MNC subsidiaries focus on ongoing business activities, sales can better reflect their performance in a dynamic business climate than fixed assets, making ROS a superior profitability indicator (Chan et al., 2008; Christmann, Day, and Yip, 1999). In addition, the Chinese government imposes tight restrictions on capital flows (Stiglitz, 2000), and ROS is therefore a better measure in this context.

\section{Measures of agglomeration}

Various measures of agglomeration have been employed in the literature. In economic geography, a common approach is to measure a jurisdiction's share in the total employment of a particular industry in a country (e.g., Rosenthal and Strange, 2003). This measure, however, does not take into account of the size of firms. For example, a high industrial concentration ratio thus calculated may just be driven by the employment figure of one large firm rather than many smaller, interconnected firms (McCann and Folta, 2008). An alternative approach, which is more commonly employed in management research, is to count the number of firms within a certain geographic area (e.g., Chang and Park, 2005). This approach, we contend, is more appropriate for studies examining a single industry than for cross-industry analysis, as it ignores the size of industries.

In this study, the degree of agglomeration is measured using a given city's share in the whole country of firms in a certain industry. More specifically, the indicator agglomeration with foreign firms is constructed as the ratio of the number of foreign firms in industry $k$ and 
year $t$ located in city $j$ to the number of foreign firms in the same industry and year in the whole country. Agglomeration with domestic firms is proxied by the ratio of domestic firms in industry $k$ and year $t$ located in city $j$ to the number of domestic firms in industry $k$ and year $t$ in the whole country. It should be noted that the two measures are based on the entire population of firms rather than just those in our sample.

The construction of our agglomeration measures controls for industry size, therefore more appropriate for the setting of a cross-industry analysis as in this study. Similar indicators have been employed in studies like Du et al (2008a, 2008b), and Shaker and Flyer (2000). We also examine the correlation of our measures with those based on employee counts and find they are highly correlated. This assures us that the use of our measures will not introduce major biases in comparison with alternative indicators.

\section{Indicator of sub-national institutions}

We use data published in World Bank (2006) to construct sub-national institutional index. The database reports information on various aspects of institutions for 120 cities in China. We focus on six items related to government effectiveness and investment climate, namely the number of days that firms spend on dealing with bureaucracies, confidence in the courts, property right protection, taxes and fees, balance between private and state-owned firms, and labour flexibility. We use principal components analysis with a varimax rotation to construct a composite index based on the six items. The procedure produces one distinct factor, on which all the items but one load nicely, with factor loadings in the range of $0.70-0.84$. The exception is the item - days spent on bureaucratic interaction, which has a factor loading 0.60 , slightly below the rule-of-thumb threshold 0.65 . In the analysis reported below, the institution index is constructed with this item included. A composite index constructed without it is also tried, and yields similar results. We construct our institution indicator in a way that the higher the index 
number, the weaker institutions. Because the World Bank data cover only one year, we use our composite index as a time-invariant variable.

\section{Control variables}

We control for several factors which affect firm profitability. For firm-specific characteristics, we include as regressors firm size, age, labour quality, leverage ratio, sales growth, a joint-venture dummy and an export dummy. Following the literature on the impact of firm size and age, we include both the variables and their quadratic terms to accommodate potential diminishing effects. We also control for city-specific factors by including road mileage (normalized by the geographic size of the city) as an indicator of infrastructure and a proxy for congestion, electricity prices as the indicator of input prices, and a coastal dummy. In addition, we include three set of dummy variables to control for the country-of-origin, year, and industry effects.

Table 1 details the definition of the variables, and Table 2 summarizes descriptive statistics, namely mean, standard deviation and pair-wise correlation. It is worth noting that the standard deviation is large for both firm profitability and city-level institution index, indicating that there are reasonable sample variation in these two variables. In addition, the coefficients of pair-wise correlation are relatively low, suggesting that multicollinearity is not a concern.

\section{(Tables 1 and 2 about here)}

\section{Estimation method}

Fixed-effect and random-effect methods are the two most commonly used estimators for panel data. The random-effect model assumes that regressors are not correlated with the unobservable individual effect. This assumption does not, however, hold true in our analysis because our sub-national institution variable may be correlated with the error term. This is due 
to a potential reverse causality between firm performance and institutional quality (i.e. highperforming foreign firms may choose to locate in locations with better institutions) and the possibility of some uncontrolled variables causing a co-evolution of foreign firms and institutional environments (Cantwell, Dunning, and Lundan, 2010; Meyer and Nguyen, 2005). The issue can, to some extent, be dealt with by adopting the fixed-effect model, but the estimator does not allow the estimation of the coefficients of time invariant variables. The index of citylevel institutions, whose effect we intend to find out, is time invariant, rendering the appropriateness of the fixed-effect method in our analysis.

Given the limitations of the above methods, we adopt the estimator developed by HausmanTaylor (1981). This method allows time-invariant regressors to be correlated with the individual effects, and accommodates endogeneity by using an instrumental variable estimator which uses both the between and within variation of exogenous variables as the instruments for the endogenous regressors. Thus, it represents an improvement to the fixed-effect and randomeffect estimators, and is more suitable for our analysis ${ }^{8}$. Applying this method to this study, we treat the sub-national institution variable as endogenous, along with the time-invariant dummy of joint venture which, according to the literature, is likely correlated with the unobservables (Li et al, 2009).

The hypotheses about the effects of agglomeration and sub-national institutions are tested by examining the coefficients of the respective variables. To examine whether agglomeration's

\footnotetext{
${ }^{8}$ The Hausman-Taylor method employs a multi-step estimation procedure with the use of instrumental variables (IV). In the first step, regression is made on time-varying variables from which within estimates and within residuals are obtained. The second step performs an IV regression of the above residuals on time-invariant variables to obtain the intermediate estimate, using exogenous variables as instrument. Next, the within estimates and intermediate estimates are used to obtain variance components based on which a GLS transformation is performed on each of the variables. The last step involves an IV regression of the transformed ROS on transformed regressors, using as instruments the within-group difference of time-varying variables, the within-group mean of exogenous time-varying variables, and exogenous time-invariant variables. This estimation method has been used in recent management research, e.g., Li, Zhou and Zajac (2009).
} 
impact differs according to the market orientation of MNC subsidiaries, we assign the sample firms to the subsample of domestic-market-oriented subsidiaries if their export/total sales ratio is below $50 \%$ and that of export-oriented subsidiaries if the ratio is $50 \%$ or above ${ }^{9}$. To find out the moderation effects of institutions on the profitability-agglomeration nexus, we construct the interaction terms between the two agglomeration measures and the city-level institution index.

\section{RESULTS}

The regression results are presented in Table 3 and Table 4 . Table 3 presents our regression results on the full sample. Model 1 shows the results with the two agglomeration variables and all control variables included. Model 2 presents the results when sub-national institution index is added. Models 3 and 4 further add the interaction terms between institutions and the two agglomeration indicators, respectively. Note that the two interactive terms should not be put into the equation simultaneously owing to possible collinearity. Table 4 presents our regression results on the sub-samples of export-focused and domestic market-focused firms.

As can be seen in Table 3, Hypotheses $1 \mathrm{a}$ and $1 \mathrm{~b}$ are strongly supported by all regressions from Models 1 to 4 . The coefficients of the agglomeration-with-foreign-firm variable are negative and significant at the 5 percent level in all the models, indicating that agglomeration with other foreign firms in the same industry has a negative impact on the profitability of foreign subsidiaries as hypothesized. The variable "agglomeration with domestic firms" registers with positive and statistically significant coefficients across the board, pointing to a positive impact on the profitability of foreign subsidiaries co-locating with domestic firms in the same industry.

\footnotetext{
${ }^{9}$ The $50 \%$ threshold level has been widely used in the literature to distinguish between domestic-market-oriented and export-oriented firms, e.g, Li, Thomas and Liu (2013), Wang et al. (2014).
} 
In Table 4, we present the results on the sub-samples of export-oriented and domestic market-oriented firms. The results in the first column indicate that the impact of agglomeration with other foreign firms is significantly negative and the impact of agglomeration with domestic firms is significantly positive for domestic market-oriented firms. However, the effects are statistically insignificant for export-oriented firms, as indicated in the results of the second column of the Table. To examine the differences of the two sub-samples further, we applied chi-square test to compare the effects of the core variables in the two sub-samples. The result of Chi-square test for the coefficients of agglomeration with other foreign firms is 2.87 , which is significant, as hypothesized. However, Chi-square test for the coefficients of agglomeration with domestic firms is not significant. Therefore, Hypothesis 2 is partially supported.

We go on to look at the results after including sub-national institution index in Model 2-4 in Table 3. In all the models which include the sub-national institution index (Models 2-4), the coefficient of the variable is negative and significant at the 1 percent level, implying that weak institutions at the sub-national level undermine the profitability of foreign firms. The coefficients of the two interaction terms between institutions and industry agglomeration are both negative and significant at the 1 percent level. We draw Figures 2 and 3 to further illustrate the moderation effect of sub-national institutions on the agglomeration-profitability nexus. Figure 2 shows that, when sub-national institutions weaken (i.e., the value of the institutional index increases), the negative effect of industry agglomeration with foreign firms tends to be amplified. Figure 3 shows that when sub-national institutions weaken (the value of the institutional index increases), the positive effect of industry agglomeration with domestic firms tends to decrease. The results support Hypotheses $3 \mathrm{a}$ and $3 \mathrm{~b}$ that weak sub-national institutions amplify the negative impact of industry agglomeration with foreign firms and attenuate the positive impact of industry agglomeration with domestic firms on foreign firm profitability. It is worth noting that all control variables but one in our four models have the expected signs and 
are statistically significant. The exception is the firm age variable, whose coefficient has the expected sign but falls short of statistical significance.

We also conduct a few robustness tests. First, we run regressions using various sub-samples, including three randomly selected sub-samples $(90 \%, 80 \%$ and $70 \%$ of the total observations respectively), a sub-sample of firms established after 1990, and that of firms with more than 40 employees. We find that the results are consistent with those obtained from the full sample. Second, we use labour productivity as an alternative measure of firm performance and obtain qualitatively equivalent results. Third, we replace the road mileage variable with an urban agglomeration indicator using the ratio of total industrial firms in city $j$ and year $t$ to the national total number of industrial firms in year $t$, which again yields results qualitatively similar to what we report here.

(Table 3 and 4 about here)

\section{(Figures 2 and 3 about here)}

\section{DISCUSSION}

This paper investigates the effects of industry agglomeration, sub-national institutions, and their interaction on the profitability of MNCs' foreign subsidiaries. Our theoretical analysis suggests that in an emerging economy like China, competition within an industry is typically more intense among foreign firms than between foreign and domestic firms. This is because foreign firms in the same industry tend to compete in the same segment of a product market and factor market. They may suffer competitively when agglomerating with other foreign firms in the same industry, owing to the fact that their technologies, employees, and access to 
supporting industries may spill over to their fiercest competitors, which in turn strengthens the competitive position of their close competitors. Fierce competition among foreign firms in the product market also tends to drive output prices down and competition for scarce local sources tends to push input costs up. As a result, industry agglomeration with foreign firms has a negative impact on the profitability of foreign subsidiaries of MNCs. In contrast, there is much weaker rivalry between foreign and domestic firms, and the former may gain from agglomerating with the latter by deriving benefits from local knowledge, networks, and other resources brought in by local enterprises. Thus, there is a positive relationship between agglomeration with domestic firms and foreign subsidiaries' profitability. The results on the sub-samples of export-oriented and domestic-market oriented firms also suggest that the impact of agglomeration with other foreign firms is different for the two groups of firms, as expected. However, the impact of agglomeration with domestic firms is statistically not different for the two groups of firms. The possible reason is that export-oriented foreign subsidiaries also benefit from agglomerating with domestic firms, for example, the local pools of skilled labour and managerial and technical staff. Furthermore, sub-national institutions moderate the above relationships by amplifying the negative impact of agglomeration with foreign firms and weakening the positive effect of agglomeration with domestic firms.

Our analysis results based on a dataset of foreign firms operating in China provide empirical evidence to support our theoretical predictions. While novel, the findings are not inconsistent with the empirical results of previous studies. The existing literature on the effects of agglomeration have been inconclusive. While earlier research focuses on the positive externalities of industry agglomeration, more recent studies have suggested that agglomeration may also generate negative externalities. In the seminal work of Shaver and Flyer (2000), the effects of agglomeration are found to depend on firms' characteristics due to firm heterogeneity. Mariotti, Piscitello, and Elia (2010) reveal that the co-locating behaviour of MNCs is influenced 
by information externalities and potential knowledge spillovers. More recently, Alcacer and Chung (2014) suggest that firms' decision about whether to locate proximately hinges upon the degree of the risk of appropriation by proximate competitors. Our study adds to this line of research by confirming that the impact of industry agglomeration depends on the types of firms with which foreign firms choose to co-locate. We find that foreign subsidiaries are positively affected by agglomerating with domestic firms and negatively impacted by agglomerating with other foreign firms. Indeed, our findings are consistent with and/or complementary to existing empirical analyses of agglomeration. For example, they corroborate the conclusion of Shaver and Flyer (2000) that firms with superior technology tend not to agglomerate with rival firms, which may otherwise lead to a negative impact on their performance, as suggested in our study. Our findings of the positive impact of industry agglomeration with domestic firms are also consistent with Alcacer and Chung (2014) in that domestic firms are not the primary and main competitors for foreign firms. Most existing studies on agglomeration focus on the location decisions of foreign firms in advanced economies like the USA (e.g., Alcacer and Chung, 2014; Shaver and Flyer, 2000) and Italy (Mariotti et al, 2010). Our study adds to the literature by examining the impact of industry agglomeration in the setting of an emerging economy, in which the analysis shows the effect differs depending on the type of firms to agglomerate with and is moderated by sub-national institutions.

We would like to sound a note of caution here, given the sample period used in our analysis. The empirical evidence of the paper derives from a period in which there was market segmentation between foreign and domestic firms and the gaps in technological capabilities between them were substantial. As mentioned earlier in the paper, competitiveness and innovative capabilities of Chinese firms have improved in recent years (Yip and Mckern, 2016) and a few firms have become world-leading names in related industries. However, such a phenomenon has only occurred to a few industries (Eberhardt et al., 2017) and only a limited 
number of Chinese firms have managed to become major competitors in the world market. As noted by Wei, Xie and Zhang (2017), although Chinese firms have demonstrated a capacity to become more innovative, the country still has a long way to go in its transition to an innovationbased economy. Interestingly, Mutlu, Zhan, Peng and Lin (2015) develop a three-round framework to explore the evolution of competitive dynamics between foreign and domestic firms in transition economies. In their framework, domestic firms are under attack of MNCs in the first round and strive to narrow the gap in terms of both technology and management in the second round, before they improve their capabilities to such an extent that they are able to compete with MNCs from developed countries in the third round. It is arguable that our theoretical framework is applicable to the first two rounds, and it is fair to say that the majority of manufacturing sectors in China have not yet embarked on the third round. Therefore, our findings still hold some validity to the situation in China now as well as in the near future before a large number of indigenous firms in a considerable number of industries emerge as worldlevel competitors. In the same token, our results hold relevance to other emerging economies which are in similar stages of liberalization and, in particular, those which have or will become new hotspots of foreign direct investment from developed countries.

Another contribution of our analysis lies with its explicit focus on profitability, which is a much less researched aspect of firm performance and arguably a better measure to accommodate the net effects of the costs and benefits of industrial agglomeration. Although limited, empirical evidence of agglomeration's impact on firm profitability is mixed. Some studies have provided evidence which casts doubt on the profitability-agglomeration relationship when agglomeration is measured as urbanization economies (or concentration of economic activity) (e.g. Jennen and Verwijmeren, 2010; Stavropoulos and Skuras, 2016). Analyses which focus on agglomeration of related firms seem to more often find statistically significant impact on profitability, although sometimes small in magnitude (e.g. Asche et al, 
2016; Nguyen et al, 2011.). Our study, which examines agglomeration with firms in the same industry, adds evidence along the latter line and enriches the related understanding by showing that co-locating with different types of firms may lead to different effects.

This study has important theoretical implications. Combining agglomeration economics and the institution-based view, we put forward theoretical arguments which go a step further from looking at only productivity gains or cost implications of agglomeration. Considering both positive and negative externalities of being located in a cluster, we provide theoretical underpinning for the profitability-agglomeration linkages and find that foreign subsidiaries suffer rather than benefit from agglomerating with other foreign firms. This finding is not necessarily in contradiction with those of Du et al. (2008a) and Martin, Salomon and Wu (2008), Both studies indicate that foreign firms tend to locate near other foreign firms, especially in weaker institutional settings, but they do not pay attention to intra-industrial market segmentation and firm competition within the same market segment. Our analytical framework which integrates agglomeration with intra-industrial market segmentation and competition is potentially applicable to other empirical contexts, in either emerging markets or industries of other types of economies where there is market segmentation. In addition, our study enriches the institution-based view by considering the moderation effect of sub-national institutions on the agglomeration-profitability nexus within the above integrated analytical framework. Until recently, research into institutions has focused mainly on the cross-country institutional variations. This study adds to the recent literature on the role of sub-national institutions (e.g., Chan et al., 2010; Du et al., 2008a; Ma et al., 2013; Meyer and Nguyen, 2005).

Our study has limitations. The sub-national institution index used in the analysis is at the city level, which, albeit better and less aggregate than indicators at the provincial level, is time invariant due to data limitation. Hopefully longitudinal data on sub-national institutions will be available in the future, allowing research to construct time-variant indices to examine their 
impact in the context of emerging economies where institutions are experiencing changes. Another limitation relates to the so-called survivor bias, given that our sample firms are winners of survival tests over the sample period and that we drop those with less than two consecutive years' data, on which we don't have information to judge whether it is due to missing data or cases of failed companies. This bias is, however a common issue faced by studies using firmlevel data in general and those drawing data from the same sources as ours and adopting similar data-trimming strategies in particular.

\section{CONCLUSIONS}

Location choice is critically important for firm performance. Many recent studies have focused on within-country location choice of foreign firms, with some examining the phenomenon of industry agglomeration. However, empirical evidence of the impact of industry agglomeration on foreign firm performance in general and profitability in particular is still scant. This paper contributes to the discourse by examining the impact of industry agglomeration on the profitability of MNC subsidiaries and the role of sub-national institutions in moderating the effect. Based on the literature of industry agglomeration and the institution-based view, we develop an analytical framework arguing that agglomeration's effect on profitability depends on the type of firms with which to co-locate. The related hypotheses are empirically tested based on a comprehensive dataset of foreign firms operating in China over the period of 1999-2005. Our analysis results suggest that the profitability of MNCs subsidiaries is negatively impacted by agglomeration with other foreign firms in the same industry and positively affected by colocating with domestic firms, and that sub-national institutions moderate the relationships by amplifying the negative impact of the former and weakening the positive effect of the latter.

The study provides several managerial and policy implications. First, MNCs need to formulate their location choice strategies by considering with whom to co-locate. In an 
emerging economic like China, they may choose to co-locate with domestic firms in the same industry which facilitate their access to local knowledge and resources. This is an advice which seems to challenge the popular conjecture that agglomeration with domestic firms leads to a leakage of technology or that domestic firms would "steal" technology from foreign firms. It is also advisable that foreign firms locate away from their foreign peers in order to avoid fierce competition and the resultant negative impact on their profitability. Second, MNCs should consider sub-national institutions when choosing regional location within an emerging economy. Traditional research has assumed that institutional environments are homogeneous within a host country. Our research reveals that the sub-national institutional environment matters and that weak sub-national institutions not only negatively affect firm performance but also moderate the agglomeration-profitability relationships. Therefore, managers of MNCs should have a clear understanding of sub-national differences in an emerging economy and formulate their location strategies accordingly. Third, the study has important implications for policy makers who are concerned about regional development. As foreign direct investment is essential for increasing productivity and creating jobs, it is desirable for policy makers to improve sub-national institutions which will in turn improve the performance of foreign firms already operating in the regions and attract more foreign investment. Such an action is particularly important for less-developed regions which may help them catch up with the betteroff areas.

\section{REFERENCES}

Alcacer J., \& Chung, W. (2014). Location strategies for agglomeration economies. Strategic Management Journal, 35 (12), 1749-1761.

Appold, S.J. (1995). Agglomeration, interorganizational networks and competitive 
performance in the U.S. metalworking sector. Economic Geography, 71 (1), 27-54.

Asche, F., Roll, K.H., \& Tveteras, R. (2016). Profiting from agglomeration? Evidence from the salmon aquaculture industry. Regional Studies, 50 (10), 1742-1754.

Bain, J.S. (1951). Relation of profit rate to industry concentration: American manufacturing, 936-1940. Quarterly Journal of Economics, 65 (3), 293-324.

Barney, J. (1991). Firm resources and sustained competitive advantage. Journal of management, 17 (1), 99-120.

Baum, J., \& Mezias, S. (1992). Localized competition and organizational failure in the Manhattan hotel industry. Administrative Science Quarterly, 37 (4), 580-604.

Beamish, P.W. (1988). Multinational Joint Ventures in Developing Countries. London, UK: Routledge.

Bental, B., \& Demougin, D. (2006). Incentive contracts and total factor productivity. International Economic Review, 47 (3), 1033-1055.

Brouthers, K.D. (2002). Institutional, cultural and transaction cost influences on entry mode choice and performance. Journal of International Business Studies, 33 (2), 203-221.

Canina, L., Enz, C.A., \&Harrison, J.S. (2005). Agglomeration effects and strategic orientations: Evidence from the US lodging industry. Academy of management journal, 48 (4), 565-581. Cantwell, J., Dunning, J.H., \& Lundan, S.M. (2010). An evolutionary approach to understanding international business activity: The co-evolution of MNEs and the institutional environment. Journal of International Business Studies, 41 (4), 567-86.

Chan, C.M., Isobe, T., \& Makino, S. (2008). Which country matters? Institutional development and foreign affiliate performance. Strategic Management Journal, 29 (11), 1179-205.

Chan, C.M., Makino, S., \& Takehiko, I. (2010). Does sub-national region matter? Foreign affiliate performance in the U.S. and China. Strategic Management Journal, 31 (11), 1226- 
1243.

Chang, S-J., \& Park, S. (2005). Types of firms generating network externalities and MNCs' colocation decisions. Strategic Management Journal, 26 (7), 595-615.

Chang, S-J. \& Xu, D. (2008). Spillovers and competition among foreign and local firms in China. Strategic Management Journal, 29 (5), 495-518.

Christmann P, Day D., \& Yip G.S. (1999). The relative influence of country conditions, industry structure, and business strategy on MNC subsidiary performance. Journal of International Management, 5 (4), 241-265.

Cohen, J.P., \& Paul, C.J.M. (2005). Agglomeration economies and industry location decisions: the impacts of spatial and Industrial spillovers. Regional Science and Urban Economics, $35(3), 215-237$.

DiMaggio, P.J., \& Powell, W.W. (1983). The iron cage revisited: Institutional Isomorphism and collective rationality in organizational fields. American Sociology Review, 48 (2), 147160.

Du, J., Lu, Y., \& Tao, Z. (2008a). FDI location choice: agglomeration vs. institutions. International Journal of Finance and Economics, 13 (1), 92-107.

Du, J., Lu, Y., \& Tao, Z. (2008b). Economic institutions and FDI location choice: Evidence from US multinationals in China. Journal of Comparative Economics, 36 (3), 412-429.

Eberhardt, M., Helmers, C., \&Yu, Z. (2017). What can explain the Chinese Patent explosion? Oxford Economic Papers, 69 (1), 239-262.

Fisman, J. H., \& Harrington, J.E. Jr. (1996). Product variety and firm agglomeration. The RAND Journal of Economics, 27 (2), 281-309.

Fisman, R. (2001). Estimating the Value of Political Connections. American Economic Review, $91(4), 1095-1102$.

Geng, W. (2012). Domestic firms missing out. People's Daily online, June 15, 2012. 
http://english.people.com.cn/90778/7846670.html.

Griffiths, A., \& Zammuto, R.F. (2005). Institutional governance systems and variations in national comparative advantage: an integrative framework. Academy of Management, 30 (4), 823-842.

Hannan, M.T., \& Carroll, R. (1992). Dynamics of organizational populations: density, legitimation, and competition. New York: Oxford University Press.

Hausman, J.A., \& Taylor, W.E. (1981). Panel data and unobservable individual effects. Econometrica: Journal of the Econometric Society, 49 (6), 1377-1398.

Henisz, W.J. (2000). The institutional environment for multinational investment. Journal of Law Economics and Organization, 16 (2), 334-64.

Hille, K., Mundy, S., \& Mishkin, S. (2012). Chinese smartphones upset the Apple cart. Financial Times, November 28, 2012. www.ft.com/cms/s/0/421c46d0-3904-11e2-981c00144feabdc0.html.

Holmes, R.M., Miller, T., Hitt, M.A., \& Salmador, M.P. (2013). The interrelationships among informal institutions, formal institutions, and inward foreign direct investment. Journal of Management, 39 (2), 531-566.

Ingram, P., \& Inman, C. (1996). Institutions, intergroup competition, and the evolution of hotel populations around Niagara Falls. Administrative Science Quarterly, 41 (4), 629-658.

Javorcik, B.S. (2004). Does foreign direct investment increase the productivity of domestic firms? In search of spillovers through backward linkages. American Economic Review, 94 (3), 605-627.

Javorcik, B.S., \& Wei, S. (2009). Corruption and cross-border investment in emerging markets: Firm-level evidence. Journal of International Money and Finance, 28 (4), 605-624.

Jennen, M., \& Verwijmeren, P. (2010). Agglomeration effects and financial performance. Urban Studies, 47 (12), 2683-2703. 
Khanna, T., \& Rivkin, J.W. (2001). Estimating the performance effects of business groups in emerging markets. Strategic management journal, 22 (1), 45-74.

Laffont, J.J., \& Tirole, J. (1991). The politics of government decision-making: A theory of regulatory capture. Quarterly Journal of Economics, 106 (4), 1089-1127.

Lamin, A., \& Livanis, G. (2013). Agglomeration, catch-up and the liability of foreignness in emerging economies. Journal of International Business Studies, 44 (6), 579-606.

Li, J., Zhou, C., \& Zajac, E.J. (2009). Control, collaboration, and productivity in international joint ventures: Theory and evidence. Strategic Management Journal, 30 (8), 865-884.

Li, X., Thomas, H., \& Liu, X. (2013). Market Orientation, Specialized Resources and Subsidiary Autonomy and Performance. Management International Review, 53 (6), 869897.

Lu, J.W., \& Xu, D. (2006). Growth and survival of international joint ventures: An externalinternal legitimacy perspective. Journal of Management, 32 (3), 427-448.

Luo, Y. (2007). From foreign investors to strategic insiders: Shifting parameters, prescriptions and paradigms for MNCs in China. Journal of World Business, 42 (1), 14-34.

Ma, X., Tong, T.W., \& Fitza, M. (2013). How much does subnational region matter to foreign subsidiary performance? Evidence from Fortune Global 500 Corporations' investment in China. Journal of International Business Studies, 44 (1), 66-87.

Marioti, S., Piscitell L., \& Elia S. (2010). Spatial agglomeration of multinational enterprises: The role of information externalities and knowledge spillovers, Journal of Economic Geography, 10 (4), 519-538.

Marshall, A. (1920). Principles of Economies (8th ed). London: Macmillan.

Martin, X., Salomon, R.M., \& Wu, Z. (2010). The institutional determinants of agglomeration: a study in the global semiconductor industry. Industrial and Corporate Change, 19 (6), $1769-1800$. 
McCann, B. \& Folta, T. (2008). Location matters: Where we have been and where we might go in agglomeration research. Journal of Management, 34 (3), 532-565.

Meyer, J.W., \& Rowan, B. (1977). Institutionalized organizations: Formal structure as myth and ceremony. American Journal of Sociology, 83 (2), 340-363.

Meyer, K.E., \& Nguyen, H.V. (2005.) Foreign investment strategies and sub-national institutions in emerging markets: Evidence from Vietnam. Journal of Management Studies, $42(1), 63-93$.

Meyer, K.E., Estrin, S., Bhaumik, S., \& Peng, M.W. (2009). Institutions, resources, and entry strategies in emerging economies. Strategic Management Journal, 30 (1), 61-80.

Mutlu, C., Zhan, W., Peng, M. \& Lin, Z. (2015). Competing in (and out of) transition economies. Asia Pacific Journal of Management, 32 (3): 571-596.

Naughton, B. (2007). The Chinese economy: Transitions and growth. MIT press.

Nguyen, D., McCracken, V., Casavant, K., \& Jessup, E. (2011). Geographic location, ownership and profitability of Washington log trucking companies. Regional Science Policy \& Practice, 3 (2), 115-125.

North, D.C. (1990). Institutions, institutional change and economic development. Cambridge: Cambridge University Press.

Olson, M. (1965). The logic of collective action. Cambridge, MA: Harvard University Press.

Peng, M.W., (2003). Institutional transitions and strategic choices. Academy of Management Review, 28 (2), 275-296.

Peng, M.W., \& Heath, P. (1996). The growth of the firm in planned economies in transition: institutions, organizations, and strategic choice. Academy of Management Review, 21 (2), $492-528$.

Porter, M.E. (1980). Competition strategy: techniques for analyzing industries and competitors. New York: Free Press. 
Porter, M.E. (1985). Competitive advantage: Creating and sustaining superior performance.

New York: Free Press.

Prescott, E.C. (1998). Lawrence R. Klein lecture 1997: Needed: A theory of total factor productivity. International Economic Review, 39 (3), 525-551.

Rose-Ackerman, S. (2001). Trust, honesty and corruption: Reflection on the state-building process. European Journal of Sociology, 42 (3), 526-570.

Rosenthal, S.S., \& Strange, W.C. (2003). Geography, industrial organization, and agglomeration. Review of Economics and Statistics, 85 (2), 377-393.

Schmalensee, R. (1989). Inter-industry studies of structure and performance. In: R. Schmalensee \& R. Willig (Ed.), Handbook of industrial economics (pp. 952-1009). Amsterdam: North-Holland.

Scott, A., \& Storper, M. (2003). Regions, globalization, development. Regional studies, 37 (67), 579-593.

Scott, W.R. (1995). Institutions and Organizations. Thousand Oaks, CA: Sage.

Shaver, J., \& Flyer, F. (2000). Agglomeration economics, firm heterogeneity, and foreign direct investment in the United States. Strategic Management Journal, 21 (12), 1175-1193.

Siba, E., Söderbom, M., Bigsten, A., \& Gebreeyesus, M. (2012). Enterprise agglomeration, output prices, and physical productivity: Firm-level evidence from Ethiopia. No. 2012/85, WIDER Working Paper.

Stallkamp, M., Pinkham, B. C., Schotter, A. P. and Buchel, O. (2017). Core or periphery? The effects of country-of-origin agglomerations on the within-country expansion of MNEs. Journal of International Business Studies, doi: 10.1057/s41267-016-0060-х.

Stavropoulos, S., \& Skuras, D. (2016). Firm profitability ad agglomeration economies: an elusive relationship. Tijdschrift voor Economische en Sociale Geografie, 107 (1), 66-80.

Stiglitz, J.E. (2000). Capital Market Liberalization, Economic Growth, and Instability. World 
Development, 28 (6), 1075-1086.

Tan, D., \& Meyer, K.E. (2011). Country-of-origin and industry FDI agglomeration of foreign investors in an emerging economy. Journal of International Business Studies, 42 (4), 504520.

Teece, D.J., Pisano, G., \& Shuen, A. (1997). Dynamic capabilities and strategic management. Strategic Management Journal, 18 (7), 509-533.

Thun, E. (2006). Changing Lanes in China: Foreign direct investment, local governments, and auto sector development. Cambridge: Cambridge University Press.

Tveteras, R., \& Batese, G.E. (2006). Agglomeration externalities, productivity and technical inefficiency. Journal of Regional Science, 46 (4), 605-625.

UNCTAD (2008). World Investment Report. The United Nations, Geneva.

Wang, J. (2012). China smartphone market 2012: Trends and analysis. DIGITIMES Research. http://www.digitimes.com/Reports/Report.asp?datepublish=2012/07/03andpages=RSands $\underline{\mathrm{eq}}=400$.

Wang, J., Wei, Y, Liu, X, Wang, C., \& Lin, H. (2014). Simultaneous Impact of the Presence of Foreign MNEs on Indigenous Firms' Exports and Domestic Sales. Management International Review. 54 (2), 195-223.

Wei, S. Xie, Z. \& Zhang, X. (2017). From "made in China" to "innovated in China": necessity, prospect, and challenges. Journal of Economic Perspectives, 32 (1): 49-70.

World Bank (2006). Governance, investment climate, and harmonious society: competitiveness enhancements for 120 cities in China. Washington: the World Bank.

Xiao, G. (2004). Round-tripping foreign direct investment and the people's republic of China. Asian Development Bank Institute Discussion Paper No. 7

Xu, C. (2011). The fundamental institutions of China's reforms and development. Journal of Economic Literature, 49 (4), 1076-151. 
Yip, G. S., \& McKern, B. (2016). China's Next Strategic Advantage: From Imitation to Innovation. MIT Press.

Yoffie D. (1993). Foreign direct investment in semiconductors. In K. Froot (Ed.), Foreign Direct Investment (pp. 197-222). Chicago: University of Chicago Press.

Zhao, M.Y. (2006). Conducting R\&D in countries with weak intellectual property rights protection. Management Science, 52 (8), 1185-99. 
Figure 1: The Theoretical Framework

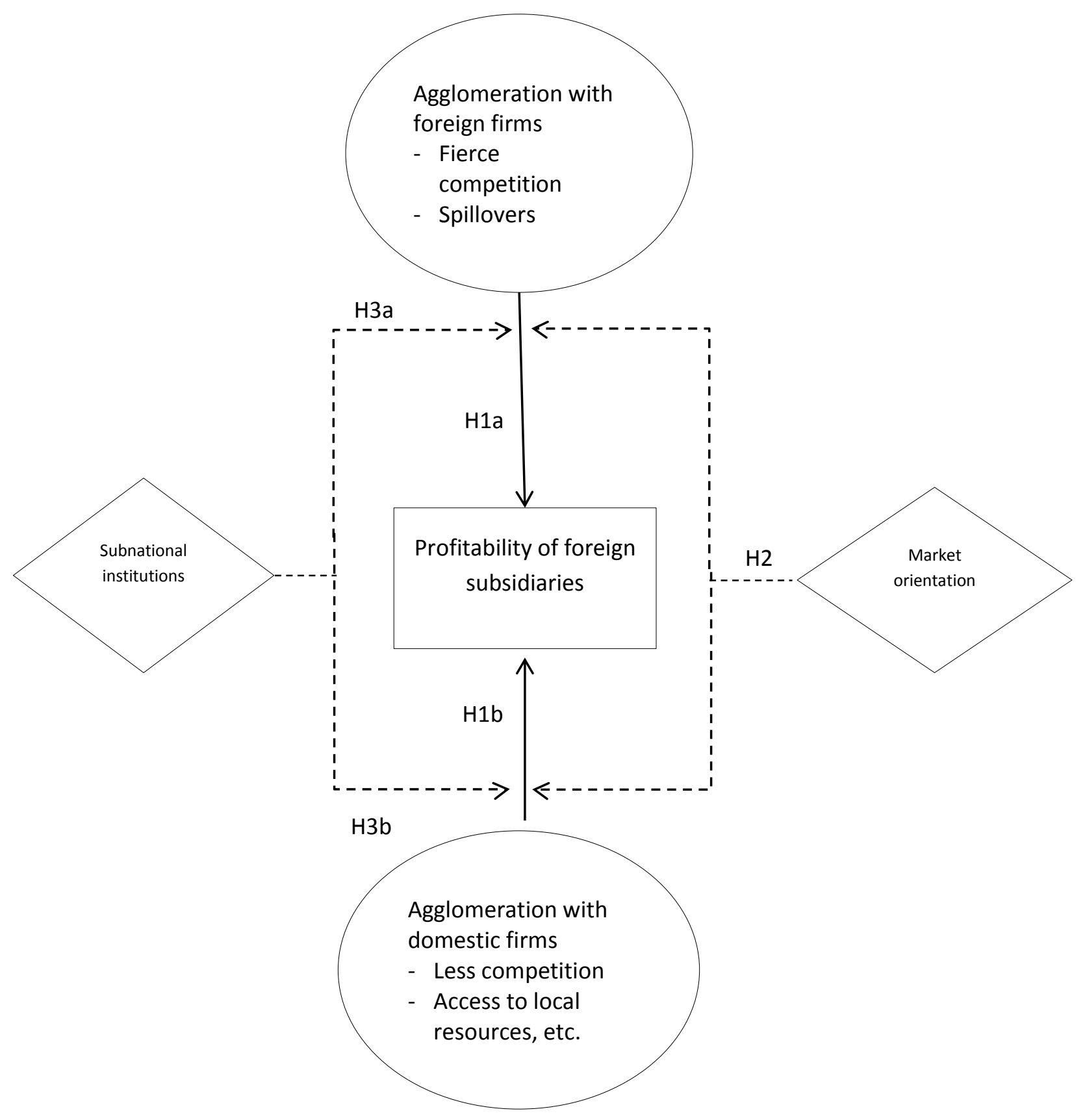




\section{Table 1: Definition of variables}

\begin{tabular}{ll}
\hline ROS & Measurement \\
Agglomeration with foreign firms & $\begin{array}{l}\text { Return on sales } \\
\text { Ratio of number of foreign firms in industry } k \text { and year } t \text { located in city } \\
j \text { to number of foreign firms in industry } k \text { and year } t \text { in the whole } \\
\text { country }\end{array}$ \\
Agglomeration with domestic firms & $\begin{array}{l}\text { Ratio of domestic firms in industry } k \text { and year } t \text { located in city } j \text { to the } \\
\text { number of foreign firms in industry } k \text { and year } t \text { in the whole country. }\end{array}$ \\
Institutional index & $\begin{array}{l}\text { Constructed based on survey data of the World Bank } \\
\text { The number of employee/1000 }\end{array}$ \\
Firm size & The number of year since established/10 \\
Joint venture dummy & 1 if the firm is a joint venture, 0 otherwise \\
Export dummy & 1 if exporting-oriented, 0 otherwise \\
Labor quality & Ratio of employees with college education \\
Sale growth & The growth of sales between t- 1 and t. \\
Leverage ratio & The ratio of debt and equity \\
Road mileage & Road mileage in the city per square kilometers \\
Electricity price & Electricity price of a city \\
Coastal dummy & 1 if a firm is located in a coastal city, 0 otherwise. \\
\hline
\end{tabular}


Table 2: Means, standard deviations, and correlations

\begin{tabular}{|c|c|c|c|c|c|c|c|c|c|c|c|c|c|c|c|c|}
\hline Variables & mean & s.d. & 1 & 2 & 3 & 4 & 5 & 6 & 7 & 8 & 9 & 10 & 11 & 12 & 13 & 14 \\
\hline ROS & 0.03 & 0.13 & 1.00 & & & & & & & & & & & & & \\
\hline Institutional index & 0.56 & 0.89 & 0.03 & 1.00 & & & & & & & & & & & & \\
\hline Agglomeration A & 0.04 & 0.04 & 0.00 & 0.10 & 1.00 & & & & & & & & & & & \\
\hline Agglomeration B & 0.03 & 0.03 & 0.01 & 0.10 & 0.69 & 1.00 & & & & & & & & & & \\
\hline Firm size & 0.32 & 0.55 & 0.04 & 0.07 & 0.03 & 0.04 & 1.00 & & & & & & & & & \\
\hline Firm age & 0.75 & 0.34 & 0.02 & -0.06 & -0.02 & -0.03 & 0.10 & 1.00 & & & & & & & & \\
\hline Export dummy & 0.71 & 0.46 & 0.05 & 0.22 & 0.08 & 0.10 & 0.15 & 0.02 & 1.00 & & & & & & & \\
\hline Labor quality & 2.66 & 0.70 & 0.13 & -0.03 & 0.11 & 0.09 & -0.01 & 0.13 & -0.03 & 1.00 & & & & & & \\
\hline Joint venture & 0.57 & 0.50 & 0.01 & -0.17 & -0.07 & 0.02 & -0.09 & 0.07 & -0.20 & -0.06 & 1.00 & & & & & \\
\hline Sales growth & 0.26 & 1.87 & 0.06 & -0.00 & 0.00 & 0.00 & 0.03 & -0.05 & -0.02 & 0.01 & -0.02 & 1.00 & & & & \\
\hline leverage & 0.52 & 0.35 & -0.25 & -0.01 & 0.01 & 0.01 & 0.02 & -0.01 & -0.02 & -0.10 & 0.04 & -0.02 & 1.00 & & & \\
\hline Road mileage & 2.31 & 0.30 & -0.01 & -0.14 & 0.02 & -0.01 & -0.10 & -0.04 & -0.07 & -0.03 & 0.07 & 0.00 & 0.01 & 1.00 & & \\
\hline Electricity price & -0.61 & 0.18 & -0.03 & -0.24 & -0.04 & -0.02 & -0.02 & 0.03 & -0.07 & 0.04 & 0.03 & 0.00 & -0.01 & 0.03 & 1.00 & \\
\hline Coastal dummy & 0.66 & 0.48 & 0.02 & 0.32 & 0.20 & 0.15 & 0.08 & 0.01 & 0.18 & 0.14 & -0.21 & 0.01 & -0.01 & -0.28 & 0.08 & 1.00 \\
\hline
\end{tabular}

Note: Agglomeration A refers to agglomeration with foreign firms; agglomeration B refers to agglomeration with domestic firms. 
Table 3: Results of Hausman-Taylor analysis

\begin{tabular}{|c|c|c|c|c|}
\hline & Model 1 & Model 2 & Model 3 & Model 4 \\
\hline \multicolumn{5}{|l|}{ Hypothesized variables } \\
\hline Agglomeration with foreign firms (A) & $\begin{array}{l}-0.017 * * \\
(0.008)\end{array}$ & $\begin{array}{l}-0.021 * * \\
(0.009)\end{array}$ & $\begin{array}{l}-0.010 * * * \\
(0.003)\end{array}$ & $\begin{array}{l}-0.017 * * * \\
(0.004)\end{array}$ \\
\hline Agglomeration with domestic firms (B) & $\begin{array}{l}0.123 * * * \\
(0.045)\end{array}$ & $\begin{array}{l}0.176 * * * \\
(0.048)\end{array}$ & $\begin{array}{l}0.129 * * * \\
(0.046)\end{array}$ & $\begin{array}{l}0.212 * * * \\
(0.072)\end{array}$ \\
\hline City-level Institutional index & & $\begin{array}{l}-0.060 * * * \\
(0.014)\end{array}$ & $\begin{array}{l}-0.006 * * * \\
(0.002)\end{array}$ & $\begin{array}{l}-0.007 * * * \\
(0.002)\end{array}$ \\
\hline A*Institutional index & & & $\begin{array}{l}-0.012 * * * \\
(0.003)\end{array}$ & \\
\hline B*Institutional index & & & & $\begin{array}{l}-0.123 * * * \\
(0.074)\end{array}$ \\
\hline \multicolumn{5}{|l|}{ Control variables } \\
\hline Firm size & $\begin{array}{l}0.030 * * * \\
(0.005)\end{array}$ & $\begin{array}{l}0.034 * * * \\
(0.005)\end{array}$ & $\begin{array}{l}0.030 * * * \\
(0.005)\end{array}$ & $\begin{array}{l}0.030 * * * \\
(0.005)\end{array}$ \\
\hline Firm size square & $\begin{array}{l}-0.003 * * * \\
(0.001)\end{array}$ & $\begin{array}{l}-0.004 * * * \\
(0.001)\end{array}$ & $\begin{array}{l}-0.004 * * * \\
(0.001)\end{array}$ & $\begin{array}{l}-0.003 * * * \\
(0.001)\end{array}$ \\
\hline Firm age & $\begin{array}{l}0.040 * * * \\
(0.011)\end{array}$ & $\begin{array}{l}0.035 * * * \\
(0.011)\end{array}$ & $\begin{array}{l}0.040 * * * \\
(0.011)\end{array}$ & $\begin{array}{l}0.041 * * * \\
(0.011)\end{array}$ \\
\hline Firm age square & $\begin{array}{l}-0.017 * * * \\
(0.006)\end{array}$ & $\begin{array}{l}-0.017 * * * \\
(0.006)\end{array}$ & $\begin{array}{l}-0.018^{* * * *} \\
(0.006)\end{array}$ & $\begin{array}{l}-0.018 * * * \\
(0.006)\end{array}$ \\
\hline Export dummy & $\begin{array}{l}0.009 * * * \\
(0.002)\end{array}$ & $\begin{array}{l}0.009 * * * \\
(0.003)\end{array}$ & $\begin{array}{l}0.009 * * * \\
(0.002)\end{array}$ & $\begin{array}{l}0.009 * * * \\
(0.002)\end{array}$ \\
\hline Labor quality & $\begin{array}{l}0.007 * * * \\
(0.002)\end{array}$ & $\begin{array}{l}0.006 * * * \\
(0.002)\end{array}$ & $\begin{array}{l}0.007 * * * \\
(0.002)\end{array}$ & $\begin{array}{l}0.007 * * * \\
(0.002)\end{array}$ \\
\hline Joint venture dummy & $\begin{array}{l}-0.106 * * * \\
(0.014)\end{array}$ & $\begin{array}{l}-0.137 * * * \\
(0.016)\end{array}$ & $\begin{array}{l}-0.110^{* * *} \\
(0.014)\end{array}$ & $\begin{array}{l}-0.104 * * * \\
(0.014)\end{array}$ \\
\hline Sales growth & $\begin{array}{l}0.005^{* * *} \\
(0.000)\end{array}$ & $\begin{array}{l}0.005 * * * \\
(0.000)\end{array}$ & $\begin{array}{l}0.005 * * * \\
(0.000)\end{array}$ & $\begin{array}{l}0.005^{* * * *} \\
(0.000)\end{array}$ \\
\hline Leverage ratio & $\begin{array}{l}-0.040 * * * \\
(0.002)\end{array}$ & $\begin{array}{l}-0.039 * * * \\
(0.002)\end{array}$ & $\begin{array}{l}-0.039 * * * \\
(0.002)\end{array}$ & $\begin{array}{l}-0.039 * * * \\
(0.002)\end{array}$ \\
\hline Road mileage & $\begin{array}{l}0.034 * * * \\
(0.008)\end{array}$ & $\begin{array}{l}0.034 * * * \\
(0.009)\end{array}$ & $\begin{array}{l}0.034 * * * \\
(0.008)\end{array}$ & $\begin{array}{l}0.034 * * * \\
(0.008)\end{array}$ \\
\hline Electricity price & $\begin{array}{l}-0.046 * * * \\
(0.010)\end{array}$ & $\begin{array}{l}-0.122 * * * \\
(0.021)\end{array}$ & $\begin{array}{l}-0.054 * * * \\
(0.013)\end{array}$ & $\begin{array}{l}-0.040 * * * \\
(0.012)\end{array}$ \\
\hline Coastal dummy & $\begin{array}{l}0.008 \\
(0.005)\end{array}$ & $\begin{array}{l}0.026 * * * \\
(0.009)\end{array}$ & $\begin{array}{l}0.004 \\
(0.006)\end{array}$ & $\begin{array}{l}0.010^{*} \\
(0.005)\end{array}$ \\
\hline Year dummies & Yes & Yes & Yes & Yes \\
\hline Industry dummies & Yes & Yes & Yes & Yes \\
\hline Home country dummies & Yes & Yes & Yes & Yes \\
\hline Wald chi-square & 808.98 & 767.19 & 790.58 & 788.64 \\
\hline
\end{tabular}

Note: figures in brackets are standard errors; $* * * \mathrm{p}<0.01, * * \mathrm{p}<0.05, * \mathrm{p}<0.1$. 
Table 4: Results of sub-group analysis

\begin{tabular}{|c|c|c|}
\hline & Domestic market-focused firms & Export-focused firms \\
\hline \multicolumn{3}{|l|}{ Hypothesized variables } \\
\hline Agglomeration with foreign firms (A) & $\begin{array}{l}-0.026 * * \\
(0.012)\end{array}$ & $\begin{array}{l}-0.016 \\
(0.018)\end{array}$ \\
\hline Agglomeration with domestic firms (B) & $\begin{array}{l}0.144 * * \\
(0.064)\end{array}$ & $\begin{array}{l}0.116 \\
(0.073)\end{array}$ \\
\hline City-level institutional index & $\begin{array}{l}-0.050 * * * \\
(0.019)\end{array}$ & $\begin{array}{l}-0.031^{*} \\
(0.018)\end{array}$ \\
\hline \multicolumn{3}{|l|}{ Control variables } \\
\hline Firm size & $\begin{array}{l}0.020 * * * \\
(0.005)\end{array}$ & $\begin{array}{l}0.047 * * * \\
(0.009)\end{array}$ \\
\hline Firm size square & $\begin{array}{l}-0.003 * * * \\
(0.001)\end{array}$ & $\begin{array}{l}-0.005^{* * * *} \\
(0.002)\end{array}$ \\
\hline Firm age & $\begin{array}{l}0.023 \\
(0.014)\end{array}$ & $\begin{array}{l}0.053 * * * \\
(0.017)\end{array}$ \\
\hline Firm age square & $\begin{array}{l}-0.009 \\
(0.008)\end{array}$ & $\begin{array}{l}-0.019 * * \\
(0.008)\end{array}$ \\
\hline Labor quality & $\begin{array}{l}0.020 * * * \\
(0.010)\end{array}$ & $\begin{array}{l}0.047 \text { *** } \\
(0.019)\end{array}$ \\
\hline Joint venture dummy & $\begin{array}{l}-0.119 * * * \\
(0.021)\end{array}$ & $\begin{array}{l}-0.093 * * * \\
(0.021)\end{array}$ \\
\hline Sales growth & $\begin{array}{l}0.005 * * * \\
(0.001)\end{array}$ & $\begin{array}{l}0.005 * * * \\
(0.001)\end{array}$ \\
\hline Leverage ratio & $\begin{array}{l}-0.023 * * * \\
(0.002)\end{array}$ & $\begin{array}{l}-0.127 * * * \\
(0.006)\end{array}$ \\
\hline Road mileage & $\begin{array}{l}0.037 * * * \\
(0.009)\end{array}$ & $\begin{array}{l}0.018 \\
(0.013)\end{array}$ \\
\hline Electricity price & $\begin{array}{l}0.030 \\
(0.024)\end{array}$ & $\begin{array}{l}-0.095 * * * \\
(0.027)\end{array}$ \\
\hline Coastal dummy & $\begin{array}{l}-0.041 * * * \\
(0.012)\end{array}$ & $\begin{array}{l}0.012 \\
(0.012)\end{array}$ \\
\hline Year dummies & Yes & Yes \\
\hline Industry dummies & Yes & Yes \\
\hline Home country dummies & Yes & Yes \\
\hline Wald chi-square & 451.39 & 791.20 \\
\hline
\end{tabular}

Note: figures in brackets are standard errors; ${ }^{* * *} \mathrm{p}<0.01,{ }^{* *} \mathrm{p}<0.05,{ }^{*} \mathrm{p}<0.1$. 
Figure 2: Moderating effect of subnational institutions on industry agglomeration with foreign firms

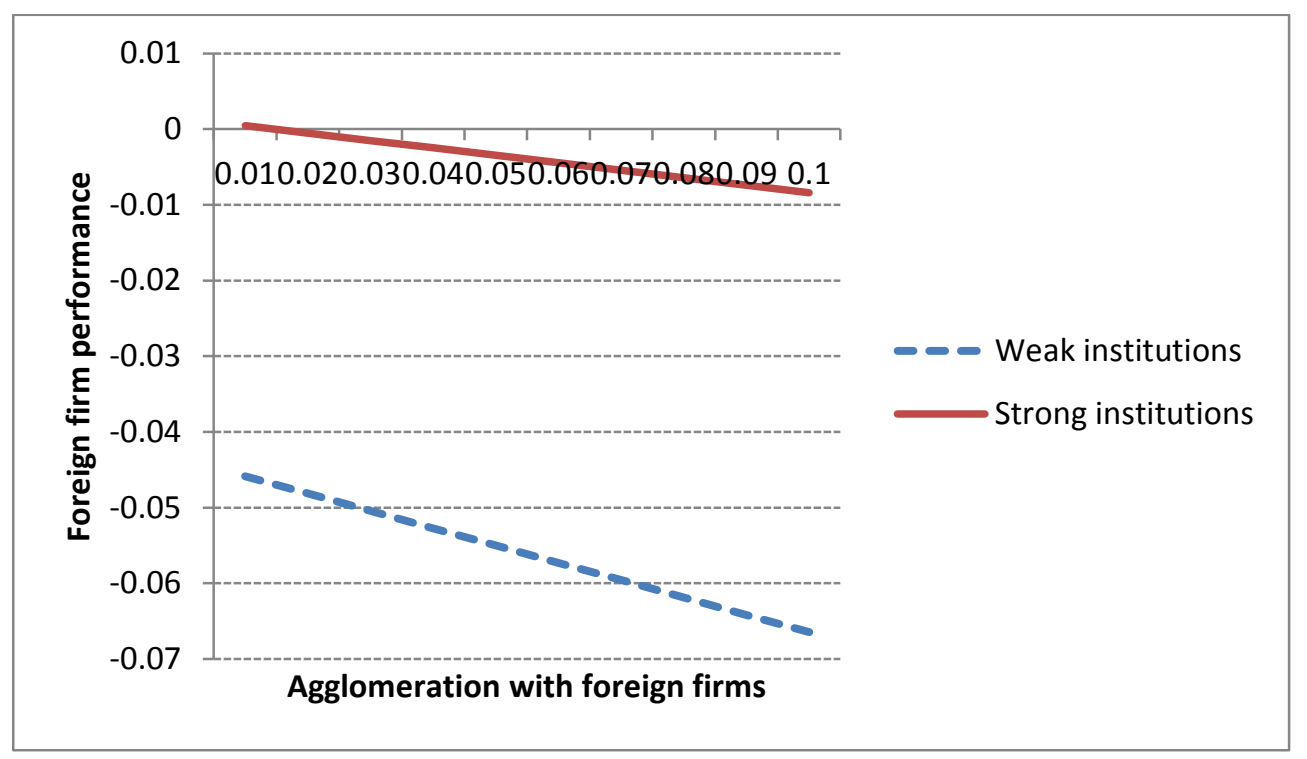

Figure 3: Moderating effect of subnational institutions on industry agglomeration with domestic firms

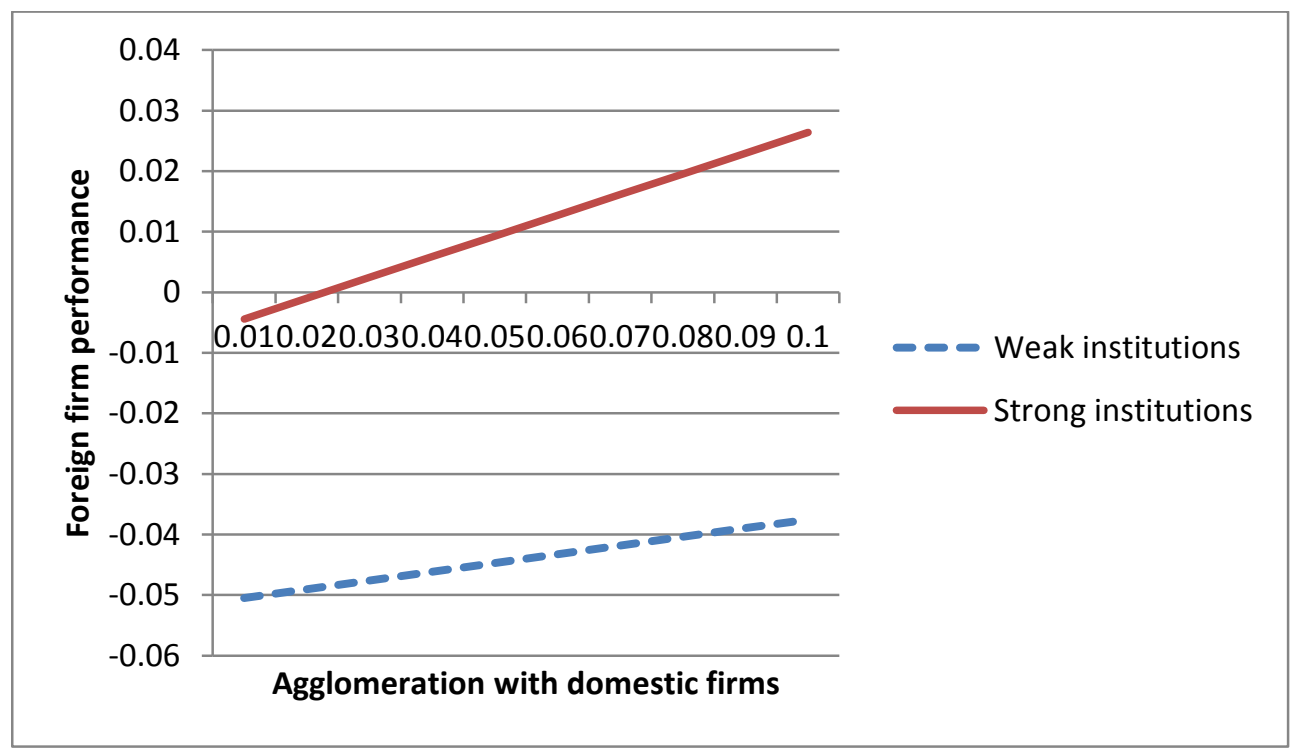

